\title{
Pelatihan Literasi Keuangan dalam Upaya Peningkatan Pemberdayaan Masyarakat Desa Pedak di Kabupaten Rembang
}

\author{
Wulan Suryandani ${ }^{1}$ dan Hetty Muniroh ${ }^{2}$ \\ 1,2 STIE YPPI Rembang, Rembang - Indonesia
}

\begin{abstract}
ABSTRAK
Program pengembangan Desa Pedak untuk peningkatan perekonomian dilakukan dengan berbagai macam program pemberdayaan masyaratat, salah satunya dengan kegiatan Usaha Peningkatan Pendapatan Keluarga (UP2K). Permasalahan dari mitra di antaranya adalah aspek manajemen keuangan, pemasaran dan manajemen usaha. Metode yang digunakan adalah pelatihan (teori dan praktik ) dan pendampingan. Adapun Hasil dari kegiatan pengabdian kepada masyarakat ini adalah Mitra memiliki kemampauan pengelolaan manajamen keuangan dan juga manajemen usaha.
\end{abstract}

Kata kunci: literasi keuangan; manajemen keuangan; pemberdayaan; UP2K PKK

\begin{abstract}
The Pedak Village development program to improve the economy is carried out with various kinds of community empowerment programs, one of which is the UP2K (Family Income Increase) activity. Problems from partners include aspects of financial management, marketing and business management. The methods used are training (theory and practice) and mentoring. The results of this community service activity are Partners have the ability to manage financial management and also business management.
\end{abstract}

Keywords: financial literacy; financial management; empowerment; UP2K PKK

\section{PENDAHULUAN}

Desa Pedak di Kecamatan Sulang, Kabupaten Rembang merupakan salah satu desa yang penduduknya mayoritas petani dengan luas wilayah 5700 ha. Secara geografis Desa Pedak di sebelah utara berbatasan dengan Desa Kedungrejo, Kecamatan Rembang, sebelah selatan berbatasan dengan Desa Peranti, sebelah barat berbatasan dengan Desa Kebonagung, dan sebelah timur berbatasan dengan Desa Landoh. Jumlah penduduk Desa Pedak 1972 jiwa, terdiri atas 930 laki-laki dan 942 perempuan dengan jumlah kepala keluarga 551 (Monografi Desa Pedak, 2014).

Program pengembangan Desa Pedak untuk peningkatan perekonomian dilakukan dengan berbagai macam program pemberdayaan masyarakat, salah satunya dengan kegiatan Usaha Peningkatan Pendapatan Keluarga (UP2K). Kegiatan pemberdayaan sebagai usaha untuk 
memberi kesempatan serta kemampuan pada kelompok masyarakat, dalam hal ini keluarga miskin, agar berani bersuara dalam menyampaikan gagasan dan pendapat serta memiliki keberanian memilih, baik bentuk, metode, produk, tindakan maupun konsep yang dipandang terbaik, tidak hanya pada keluarga dan pribadi tapi juga bagi masyarakat (Haris, 2014).

Upaya Peningkatan Pendapatan Keluarga Pendidikan Kesejahteraan Keluarga (UP2K PKK) merupakan salah satu program penanggulangan kemiskinan dengan sasaran kaum perempuan (Aryanto et al., 2019). Pada program pengabdian masyarakat tahun 2019, tim pengabdian STIE YPPI Rembang mendampingi kegiatan pengelolaan usaha simpan pinjam UP2K Bina Bersama. Selain mengelola simpan pinjam UP2K juga mengembangkan produk makanan berbasis kearifal lokal Desa Pedak berupa krupuk siwalan dan minuman kesehatan dari siwalan yang terbuat dari genjieser (legen, jahe, sereh). Krupuk siwalan dijual dengan harga Rp 5.000, dan minuman Genjiser Rp 7.000 per botol.

Usaha produk makanan yang dikembangkan UP2K ini dikelola oleh ibu-ibu PKK sejak bulan Agustus 2019. Produk makanan tersebut menggunakan bahan baku siwalan. Buah siwalan banyak ditemui di Desa Pedak yang umumnya dijual secara langsung. Akan tetapi buah siwalan yang cukup tua tidak dapat dimakan karena teksturnya menjadi keras. Buah siwalan tua dimanfaatkan oleh Mitra, diolah menjadi kerupuk. Usaha yang dijalankan mulai tahun 2019 itu masih banyak menghadapi kendala dalam pengembangannya.

Beberapa kendala yang dihadapi dari usaha UP2K PKK adalah keterbatasan kemampuan SDM dalam mengembangkan usaha, diantaranya adalah terbatasnya pemasaran, pengelolaan manajemen produksi, dan manajemen keuangan. Kapasitas sumber daya manusia pengelola UP2K PKK dalam pengelolaan manajemen produksi relatif rendah sehingga tidak memiliki kemampuan mengelola manajamen usaha yang baik, hal ini dibuktikan dengan tidak adanya pengelolaan manajemen keuangan. Teknik pemasaran juga hanya dilakukan secara langsung kepada pembeli tanpa ada strategi pemasaran, serta kurangnya motivasi dalam mengembangkan usaha.

Permasalahan manajemen keuangan adalah tidak adanya kemampuan menghitung biaya produksi serta membuat laporan keuangan sederhana. Pelaku usaha mengelola usahanya tanpa memiliki dasar pengetahuan maupun ketrampilan manajemen usaha dan manajemen keuangan. Manajemen keuangan yang baik akan membantu pengusaha untuk mengontrol usaha dan membuat keputusan terkait dengan usaha yang dilakukan (Fauzi, 2020). Permasalahan yang dihadapi UP2K PKK dalam pengelolaan produk pemasaran adalah kurangnya strategi pemasaran serta dukungan media pemasaran.

Program pengabdian masyarakat ini diharapkan dapat membantu menyelesaikan permasalahan pada mitra. Selain itu diperlukan juga pendampingan terhadap usaha tersebut melalui Tim Pengabdian Kepada Masyarakat STIE YPPI Rembang, dengan cara memberi solusi 
dan alternatif pemecahan masalah yang dihadapi dalam meningkatkan kemampuan manajemen terutama dalam manajemen keuangan, pemasaran dan manajemen usaha.

\section{METODOLOGI PELAKSANAAN}

Permasalahan dari mitra pada aspek manajemen keuangan, pemasaran dan manajemen usaha, tidak semuanya dapat diselesaikan dalam pelaksanaan kegiatan ini. Untuk itu prioritas permasalahan yang disepakati untuk diselesaikan dalam program ini adalah: (1) manajemen keuangan, diselesaikan dengan pelatihan manajemen keuangan dan pembuatan laporan keuangan; (2) manajemen usaha, diberikan pelatihan kewirausahaan dan motivasi usaha.

Metode pendekatan yang ditawarkan untuk menyelesaikan persoalan mitra (Gambar 1) adalah: (1) mefasilitasi penguatan peran kelompok agar mampu meningkatkan kemampuan pengelolaan keuangan yang baik dari aspek administrasi dan manajemen keuangan; (2) melakukan pelatihan manajemen, mencakup: penghitungan biaya pokok produksi, penentuan harga jual, perhitungan rugi laba dan pembuatan laporan keuangan sederhana; (3) pelatihan motivasi usaha dan kewirausahaan, sehingga mitra memiliki kemampuan dalam pengembangan usaha; (4) pendampingan, dilakukan oleh tim bersama mitra untuk pemantapan progam dalam jangka waktu satu bulan.

Gambar 1. Permasalahan dan Solusi yang Ditawarkan

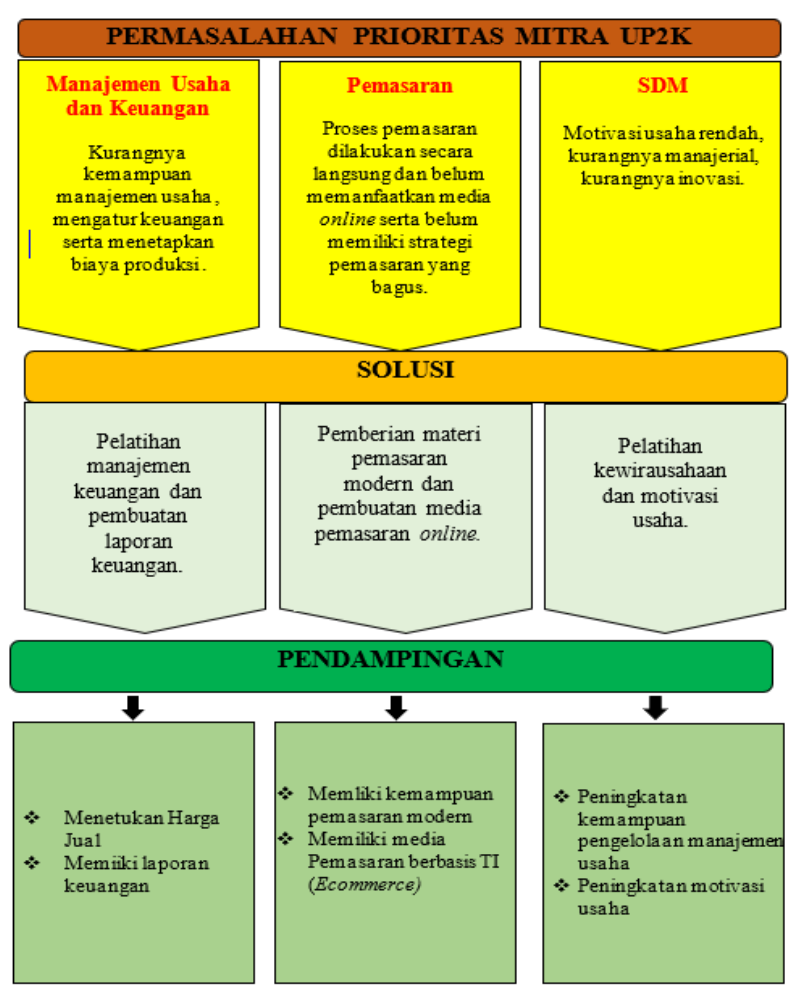




\section{HASIL DAN PEMBAHASAN}

Hasil dan luaran kegiatan pengabdian kepada masyarakat ini meliputi: (1) pelatihan manajemen keuangan; (2) Pelatihan motivasi usaha dan manajemen usaha; (3) upaya pendampingan; (4) monitoring dan evaluasi.

Pelatihan Manajemen Keuangan dilaksanakan Selasa, 13 Oktober 2020 pukul 09.00 WIB dengan pemateri ketua tim, Wulan Suryandani, SE., MM. Peserta pelatihan adalah anggota kelompok UP2K PKK Desa Pedak. Materi yang disampaikan antara lain penentuan harga pokok produksi (HPP) dan harga jual produk karena Mitra mengalami masalah dalam penentuan HPP dan harga jual produk.

Dengan adanya pelatihan ini akan memudahkan Mitra dalam menentukan HPP dan harga jual produk. Materi selanjutnya adalah membuat pelaporan arus kas sederhana sehingga Mitra diharapkan bisa mengetahui berapa pengeluaran dan pemasukan dalam kegiatan usaha, diikuti dengan materi penentuan laba-rugi secara sederhana sehingga Mitra mengetahui cara menghitung laba dan rugi yang didapatkan dari kegiatan usaha. Pelatihan berjalan dengan lancar dan peserta dapat mengikuti dengan baik materi yang disampaikan oleh pemateri.

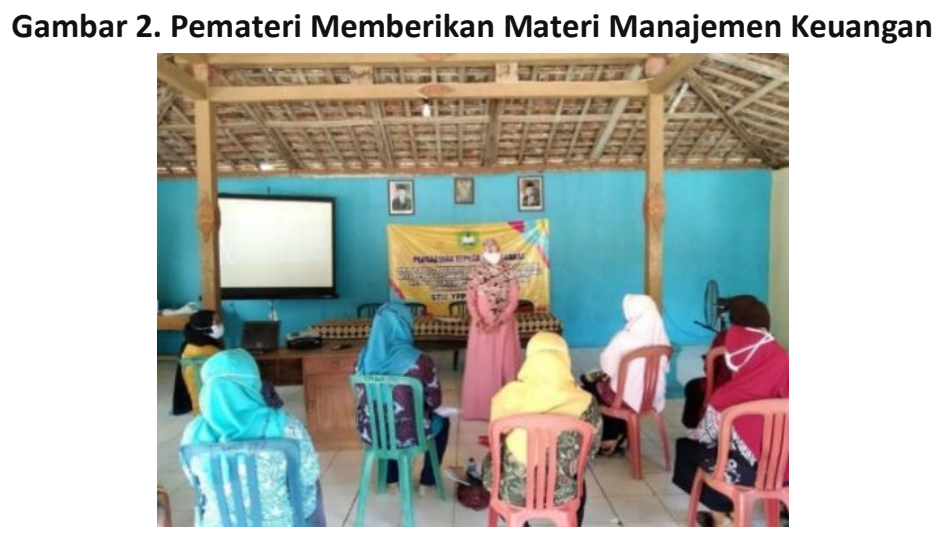

Upaya Pendampingan diadakan setelah kegiatan pelatihan 13 Oktober 2020 selesai dilaksanakan. Upaya pendampingan tahap pertama diselenggarakan Sabtu, 7 November 2020. Pendampingan dilakukan oleh Ketua Tim Pengabdian, Anggota dan dua Mahasiswa STIE YPPI Rembang. Pendampingan yang dilakukan adalah membantu Mitra dalam menentukan HPP dan harga jual produk. Menentukan HPP dan harga jual dapat membantu Mitra untuk mendapatkan laba rugi yang sesuai sehingga usaha dapat berkembang.

Selain pendampingan manajemen keuangan, Mitra juga didampingi dalam pembuatan laporan laba rugi secara sederhana. Dengan melakukan rekap order secara rutin dan juga pencatatan biaya-biaya yang dikeluarkan, maka Mitra mampu menentukan laba rugi usaha. 
Untuk membantu pemasaran produk UP2K PKK yaitu Krusil (Krupuk Siwalan) dan juga Genjaeser (minuman kesehatan dari legen, jahe dan sereh), tim membantu membuatkan logo produk dan kemasan yang lebih menarik untuk meningkatkan penjualan produk, sehingga diharapkan dengan logo dan kemasan baru tersebut penjualan produk bisa meningkat dan produk makin dikenal oleh pasar.

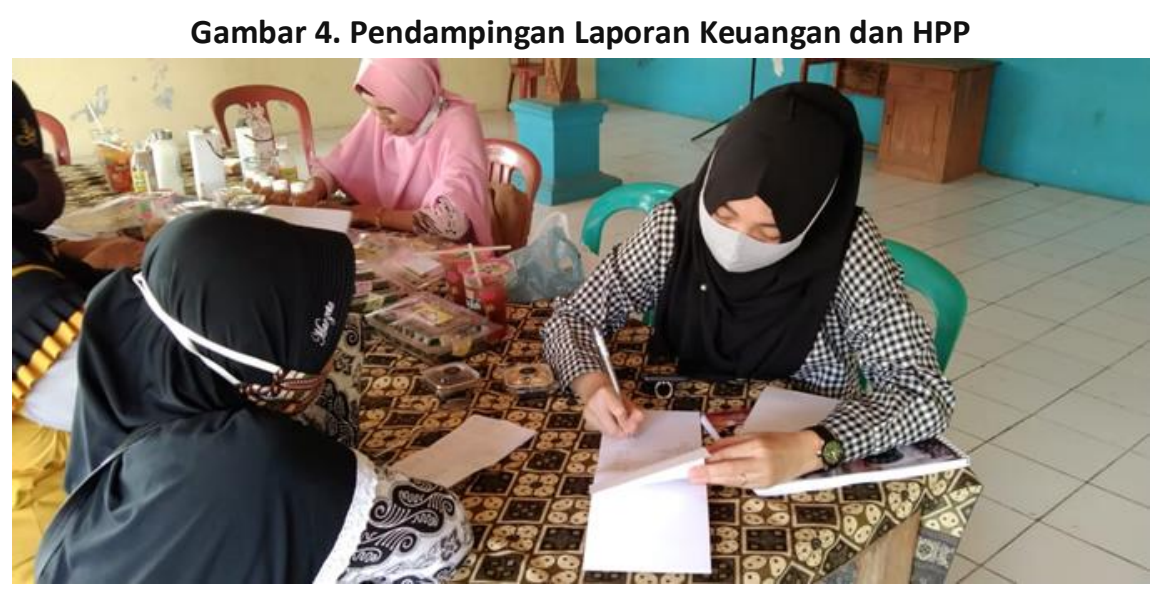

\section{Monitoring dan Evaluasi}

Pelaksanaan kegiatan pelatihan dan pendampingan mengalami hambatan antara lain penentuan alokasi waktu pelaksanaan, karena berkaitan dengan kesiapan peserta dan juga tim pelaksana. Selain itu pada kegiatan pelatihan dan pendampingan tidak semua peserta memiliki kemampuan yang sama dalam menerima pelatihan dan pendampingan sehingga hanya beberapa orang yang aktif dalam kegiatan pendampingan.

Proses monitoring dan evaluasi Program Pengabdian Kepada Masyarakat dilakukan oleh pihak LPPM STIE YPPI Rembang. Proses evaluasi di UP2K PKK Desa Pedak dilakukan dengan melakukan komunikasi secara intens ke pihak UP2K PKK membahas kendala-kendala yang dihadapi UP2K PKK seperti kesulitan membuat laporan keuangan sesuai dengan standar akuntansi.

\section{SIMPULAN}

Hasil pelaksanaan kegiatan Pengabdian Kepada Masyarakat di Desa Pedak, Kabupaten Rembang, dapat disimpulkan sebagai berikut: (1) materi pelatihan terkait berupa manajemen keuangan, motivasi usaha dan manajemen usaha disampaikan oleh pemateri yaitu Dosen STIE YPPI Rembang; (2) materi yang disajikan dapat diterima, dipahami, dan dimengerti dengan baik oleh peserta; (3) kegiatan pelatihan dan pendampingan berjalan sesuai dengan rencana dan berjalan dengan lancar. 


\section{DAFTAR PUSTAKA}

Aryanto, S., Sudaryanto, Sajati, H., Kusumaningrum, A., Nugraheny, D., \& Wintolo, H. (2019). Pengembangan Kewirausahaan Bagi UP2K-PKK Kelurahan Prawirodirjan Gondomanan Yogyakarta Untuk Mendukung Pemasaran Produk Menggunakan Instagram. KACANEGARA, 2(2), 81-88. http://dx.doi.org/10.28989/kacanegara.v2i2.442

Fauzi, H. (2020). Pelatihan Manajemen Keuangan Bagi Pelaku UMKM Sebagai Upaya Pengautan UMKM Jabar Juara Naik Kelas. BERNAS: Jurnal Pengabdian Kepada Masyarakat, 1(3), 247-255. https://doi.org/10.31949/jb.v1i3.324

Haris A, (2014), Memahami Pendekatan Pemberdayaan Masyarakat Melalui Pemanfaatan Media. JUPITER, XIII(2), 50-62.

Oktaviani, F. \& Rustandi, F. (2018). Implementasi Digital Marketing dalam Membangun Brand Awareness. PRofesi Humas, 3(1), 1-20. https://doi.org/10.24198/prh.v3i1.15878

Sudaryanto, Sajati, H., Kusumaningrum, A., Nugraheny, D., Aryanto, S., \& Wintolo, H. (2020). Pendampingan Pemasaran Produk Menggunakan Instagram Bagi Pelaku Usaha Mikro Kecil Menengah (UMKM) di Kecamatan Pathuk Gunung Kidul. KACANEGARA, 3(1), 6168. http://dx.doi.org/10.28989/kacanegara.v3i1.524 